\title{
Gastropod molluses as indicators of the cadmium natural inputs in the Canarian Archipelago (Eastern Atlantic Ocean)
}

\author{
R. Ramírez, C. Collado, O. Bergasa, J. J. Hernández \\ \& M. D. Gelado \\ Department of Chemistry, BIOGES, \\ University of Las Palmas de Gran Canaria, Spain
}

\begin{abstract}
Nowadays, gastropod molluscs are being utilized more and more as bioindicator organisms. Similarly, harmful metals on human health such as cadmium have been widely studied. The Canarian Archipelago (specifically the eastern islands) is constantly bathed by the African coastal upwelling, provoking oceanographic and biological differences between the islands. This process could assume an increase in the Cd concentration in their coastal waters and in the biota. Thus, in order to assess this fact, we measured cadmium concentrations in the soft parts of two species of limpets (Patella rustica and Patella candei crenata) and in a topshell snail (Osilinus atrata). Metal determination was performed using atomic absorption spectrometry (AAS). We found significant differences for metal concentrations between the eastern islands and the western islands for all species. $P$. rustica, $P$. c. crenata and $O$. atrata presented values ranging from $7.71,2.11$ and $7.56 \mu \mathrm{g} \mathrm{g}^{-1}$ dry wt. (eastern islands) to $1.38,0.4$ and $1.08 \mu \mathrm{g} \mathrm{g}^{-1}$ dry wt. (western islands) respectively. Therefore, we concluded that limpets and topshell snails seem to be suitable indicators of the cadmium concentrations in the coastal waters of the Canary Islands.

Keywords: Canary Islands, heavy metals, cadmium, gastropod molluscs, Patella rustica, Patella candei crenata, Osilinus atrata.
\end{abstract}




\section{Introduction}

Cadmium (i.e. Cd) is a non-essential metal for life and it can be toxic even at low concentrations. Its harmful effects on humans have made it one of the most studied metals. In the oceans, its concentration is related with the nutrients phosphate and nitrate concentrations [1]. Besides, all of them present higher concentrations in deep waters than in the ocean surface. In contrast to this, $\mathrm{Cd}$ can be found at higher concentrations in the surface waters when a coastal upwelling process has happened [1]. Furthermore, any increase in the $\mathrm{Cd}$ load in the nearshore waters can have an immediate effect on the levels of this metal in the biota [2]. In this sense, organisms can be reflecting into their bodies an increase in the local bioavailability of the metal due to natural and human inputs. Thus, molluscs represent one of the best groups of the animal kingdom to be utilized as bioindicators [3].

The Canary Islands lie in a transition zone between the oligotrophic open ocean and the northwest African upwelling region (so-called Northwest African Coastal Transition Zone [NACTZ]) [4]. Quasi-permanent filaments of these waters reach the eastern islands (Chinijo Archipelago, Lanzarote, Fuerteventura and Gran Canaria) of the Canarian Archipelago. As a result, eastern and western islands present differences in their oceanographic characteristics $[5,6]$. In addition, in the rocky coasts of the Canary Islands exist several species of gastropods molluscs, like limpets and topshell snails. These could be utilized as bioindicators for metal entrances in the coastal environments, such as what has been done in other geographical areas (e.g., [7-11]). We must take into account that food is one of the major entrance of $\mathrm{Cd}$ into humans [2]. In our case, the limpets and topshell snails are widely harvested and consumed by local people throughout the Canarian Archipelago [12, 13]. This could suppose a harmful metal transfer that, until now, has not been valued in the realized medical studies [14].

Therefore, our objective was to determine if the limpets (Patella rustica and Patella candei crenata) and the topshell-snail (Osilinus atrata) can be used as indicators for the natural inputs of $\mathrm{Cd}$ in the Canarian Archipelago.

\section{Material and methods}

\subsection{Study area and sampling}

Our study was carried out in the Canary Islands $\left(13-19^{\circ} \mathrm{W}, 27-30^{\circ} \mathrm{N}\right)$, in March 2003 (Figure 1). Organisms were randomly handpicked from each location (three per islands) according to their availability. Specimens of Patella candei crenata were not found in Fuerteventura Islands and Patella rustica was not found in El Hierro Islands. Samples (P. rustica, $\mathrm{n}=104$, P. candei crenata, $\mathrm{n}=121$, Osilinus atrata, $\mathrm{n}=112$ ) were placed in polypropylene bags and transported to the laboratory where each individual was measured (total length), rinsed with deionized water (Mili-Q, Millipore, $18 \mathrm{M} \Omega \mathrm{cm}$ ), and frozen in new bags until the digestion processed $[15,16]$. 


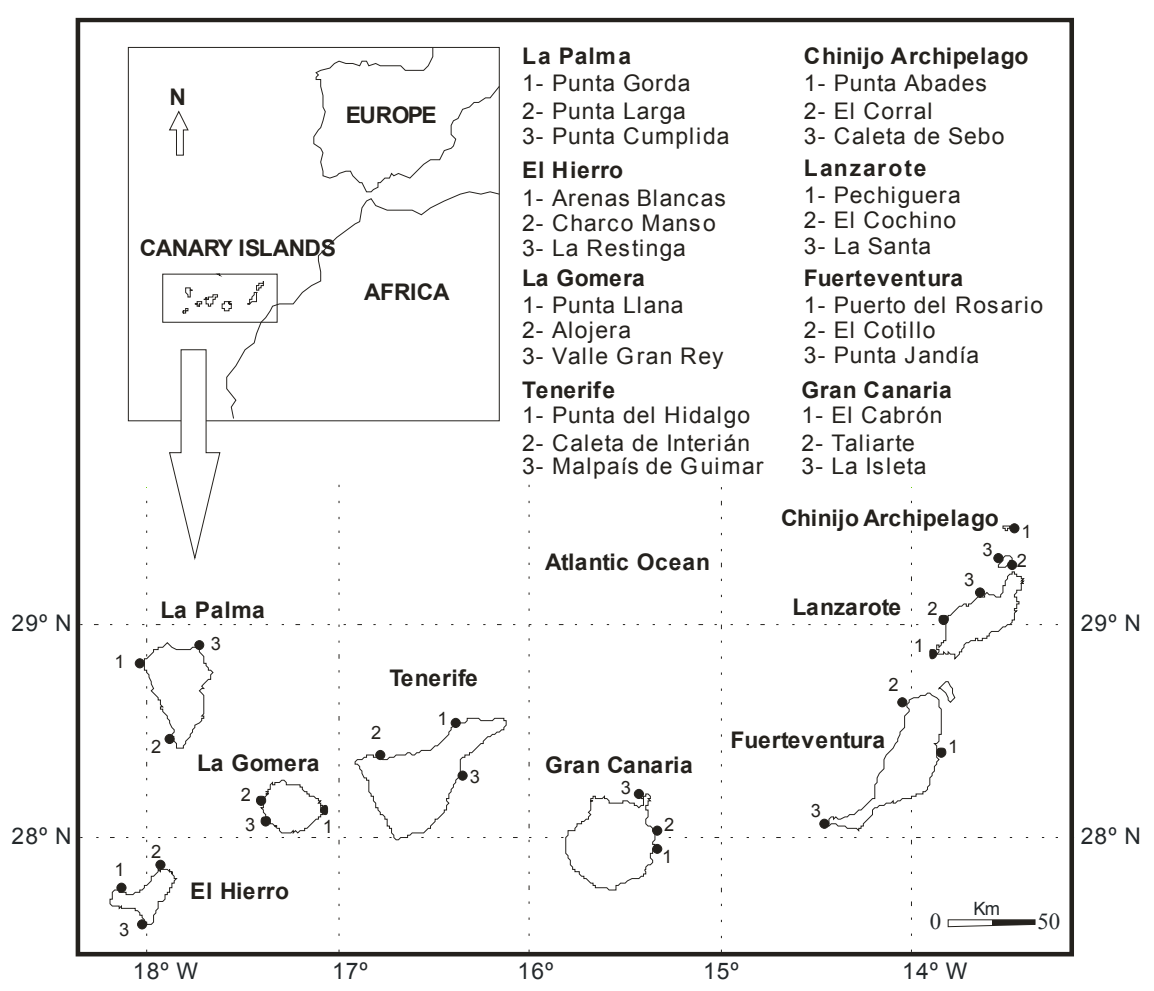

Figure 1: Map of the study area which shows the locations where the mollusc samples were recollected.

\subsection{Analysis}

Metal determination requires careful sample handling, storage and analysis. Therefore, all plastic materials were previously treated with an acid cleaning. It consisted in successive rinsing with diluted nitric $(0.3 \mathrm{M})$ and hydrochloric $(0.1 \mathrm{M})$ acid solutions for 72 hours, and washing with water of analytic quality (Millipore Milli-Q system, $18 \mathrm{M} \Omega . \mathrm{cm})[15,16]$.

We proceed to extract the soft tissues from their shells and to clean them to remove the salts and impurities. To obtain the dried weight, the samples were dried with a IR lamp until constant weight $(48 \mathrm{~h})$. Then, the samples digestion was carried out on a hot plate for $3-4 \mathrm{~h}$ at $120^{\circ} \mathrm{C}$, using a mixture of nitric and perchloric acids with a $2: 1$ ratio $(4 \mathrm{ml}: 2 \mathrm{ml})$. Finally, the residual acids solutions were diluted up to $100 \mathrm{ml}$ with Mili-Q deionized water.

The metal concentrations analysis was calculated using atomic absorption spectrometry (AAS). In particular, the $\mathrm{Cd}$ concentration was performed by graphite furnace atomic absorption spectrometry (GFAAS). Besides, for its determination a matrix modifier was used $\left(\mathrm{NH}_{4} \mathrm{H}_{2} \mathrm{PO}_{4}\right)$. Data quality control was provided by a separate comparative study of a standard reference material (BCR 
CRM 278-mussel tissue). This was satisfactory showing a recovery of $86.50 \%$. Each sample, blanks and the certified reference material were carried out in triplicate.

\subsection{Statistical analysis}

Mean metal concentrations together with standard errors were calculated for overall registered data. To check up on the differences in the metal levels the Kruskal-Wallis test was previously used for each species. Non-parametric MannWhitney U-tests were then conducted to test the significance of the differences in the metal concentrations among islands. Associations between size, weight and $\mathrm{Cd}$ concentration were studied by means of non-parametric Spearman correlation coefficient. All analysis were performed using the package SPSS version 12 (C) software for Windows XP.

\section{Results}

The mean total concentrations of Cd for Patella rustica, Patella candei crenata and Osilinus atrata were $3.61 \pm 0.45,0.71 \pm 0.10$ and $2.55 \pm 0.45 \mu \mathrm{g} \mathrm{g}^{-1}$ dry wt. (mean \pm S.E) respectively. Similarly, the mean total size and weight from overall individuals analysed were $27.37 \pm 0.40,38.08 \pm 0.58$ and $16.48 \pm 0.35(\mathrm{~mm} \pm$ S.E) for the size, whereas the weight were as follows $0.32 \pm 0.02,0.33 \pm 0.02$ and $0.11 \pm 0.01(\mathrm{~g} \pm \mathrm{S}$.E) for $P$. rustica, $P$. candei crenata and $O$. atrata respectively. With respect to the islands, the maximum concentrations were found in the Chinijo Archipelago $\left(7.71 \pm 1.39 \mu \mathrm{g} \mathrm{g}^{-1}\right.$ dry wt., P. rustica; $7.56 \pm 0.83 \mu \mathrm{g} \mathrm{g}^{-1}$ dry wt., O. atrata) and Lanzarote $\left(2.11 \pm 0.73 \mu \mathrm{g} \mathrm{g}^{-1}\right.$ dry wt., $P$. c. crenata) (Figure 2). We also observed a high value for $O$. atrata $\left(4.34 \pm 0.83 \mu \mathrm{g} \mathrm{g}^{-1}\right.$ dry wt.) in La Palma. In contrast to this, the minimum values were registered in La Palma for the limpet $P$. rustica $\left(1.38 \pm 0.48 \mu \mathrm{g} \mathrm{g}^{-1}\right.$ dry wt.) and in Gran Canaria for P. c. crenata and $O$. atrata $(0.25 \pm 0.16$ and $0.58 \pm 0.07$ $\mu \mathrm{g} \mathrm{g}^{-1}$ dry wt. respectively) (Figure 2).

For each species, we have detected significance differences $(p<0.01)$ between the studied islands (Kruskal-Wallis test). The results obtained with the Mann-Whitney U-tests are reported in the table 1 . The $\mathrm{Cd}$ showed a tendency from eastern (high concentrations) to western islands (low concentrations) with great significant differences (Table 1).

Only positive correlations were found between the size and the $\mathrm{Cd}$ concentrations for Patella candei crenata $(\mathrm{r}=0.219, \mathrm{p}=0.02)$ and Osilinus atrata $(\mathrm{r}=0.292, \mathrm{p}<0.01)$. However, for Patella rustica we did not registered any relationship between this biometric parameter and the $\mathrm{Cd}$ concentrations. Strong correlations were detected between the size and weight of the three species $(0.689$, P. rustica; $0.746, P$. c. crenata and $0.971, O$. atrata; $\mathrm{p}<0.0001)$. On the other hand, for all species the weight did not show any relationship with the measured $\mathrm{Cd}$ concentrations. 


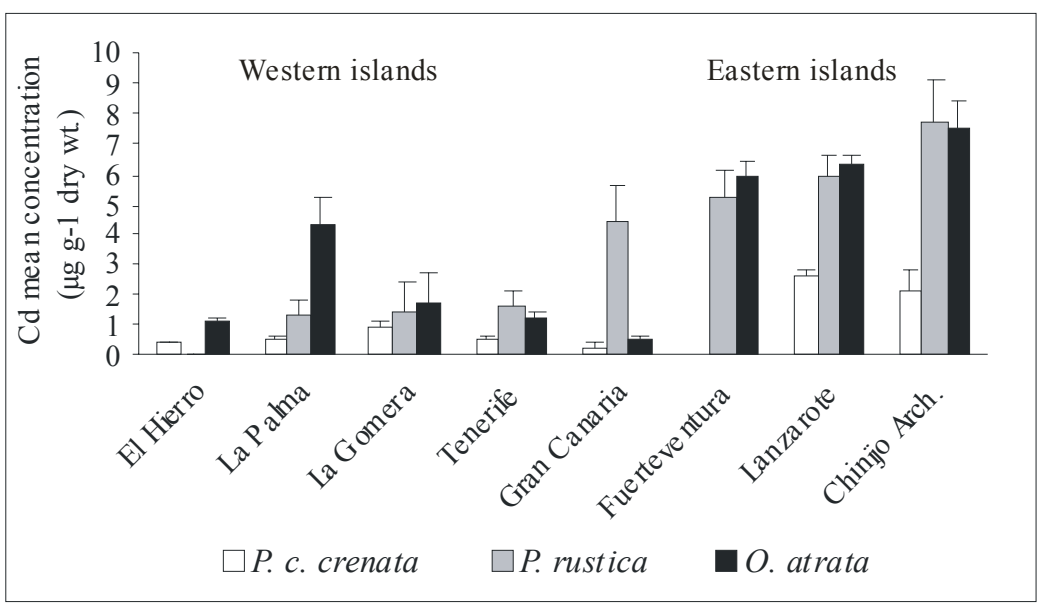

Figure 2: $\quad$ Mean concentration of $\mathrm{Cd}\left(\mu \mathrm{g} \mathrm{g}^{-1}\right.$ dry wt. \pm S.E $)$ in the three studied gastropods throughout the Canarian Archipelago.

Table 1: Differences on metal concentration obtained for the different islands using the U-Mann Whitney tests.

\begin{tabular}{ccc}
\hline \multicolumn{3}{c}{ Level of significance } \\
\hline $0.01<\mathrm{p}<0.05$ & $0.001<\mathrm{p}<0.01$ & $\mathrm{p} \leq 0.001$ \\
\hline
\end{tabular}

$\begin{array}{lll} & \text { CA-F, CA-GC, F-G, CA-G, GC-T } & \text { CA-T, CA-P, L-T, } \\ \text { P. rustica } & \text { GC-P } & \text { L-G, L-P, F-T, F-P }\end{array}$

O. atrata

CA-GC, CA-T, CAG, CA-H, L-GC, LT, L-G, L-H, F-GC, F-T, F-G, F-H, GCT, GC-G, GC-P, T$\mathrm{P}, \mathrm{G}-\mathrm{P}, \mathrm{P}-\mathrm{H}$

CA: Chinijo Archipelago, L. Lanzarote, F: Fuerteventura, GC: Gran Canaria, T: Tenerife, G: La Gomera, P: La Palma; H: El Hierro 


\section{Discussion}

Our results have shown a clear tendency of the $\mathrm{Cd}$ concentrations from the eastern to western islands. Besides, this accumulation pattern at regional scale is constant for the three studied species of gastropod molluscs. We have not found a clear reason to explain the relatively high peak of $\mathrm{Cd}$ that was found for Osilinus atrata in La Palma. Differences between the oceanographic characteristics (e.g., T ${ }^{\mathrm{a}}$, salinity, nutrients concentration, etc) in the Canarian Archipelago have been shown in multitude of works (e.g., [5, 6, 17]). This variation can imply changes at biological level of the populations (e.g., abundance) (e.g., [18, 19]). Moreover, our work show that the upwelling process which takes place in the northwest coast of Africa, provoke physiological alterations under a chemical point of view. In this sense, there are evidences that associate $\mathrm{Cd}$ concentrations with these kinds of events, such as what have occurred in Baja California and the Moroccan coast for two different species of mussels [20, 21].

On the other hand, $\mathrm{Cd}$ concentrations obtained in the eastern islands were similar for $P$. rustica and $O$. atrata, whereas $P$. c. crenata showed lower concentrations. It is known that the gastropods related species may exhibit distinct accumulation strategies for heavy metals [22-25]. The studied gastropods present some differences regarding to their vertical distributions (tidal height of habitat) in the intertidal zone of the Canary Islands [12]. It could affect to their food supply (type of microalgae) and consequently provoke differences in the metals uptake $[11,26,27]$. Thus, an enhance in local bioavailability of $\mathrm{Cd}$, whether dissolved or in the diet, can cause an increase in the uptake rate of that metal into the body [24, 28]. In consequences, $\mathrm{Cd}$ variations into their bodies seem to be due to external facts more than to the individuals' characteristics.

Finally, biometrics parameters showed light or none relationships with the $\mathrm{Cd}$ levels found in the studied molluscs. Despite to this, the correlations were always positive as it was observed in the Mediterranean area with similar gastropod species [11]. This means that the largest individuals presented higher lightly $\mathrm{Cd}$ concentrations than those found in the smaller individuals. Even though, we need more information to clarify the actual accumulation patterns of these species, taking into account other parameters such as season variations, sex, reproductive stage, etc and to include new possible species as bioindicators.

\section{Conclusion}

We concluded that limpets (Patella rustica and Patella candei crenata) and topshell snails (Osilinus atrata) could be suitable organisms to be used as indicators in the Canary Islands. They clearly reflect the $\mathrm{Cd}$ natural inputs in the Canarian Archipelago coming of the African up-welling zone. 


\section{References}

[1] Bruland, K. W. Trace elements in sea-water, in Riley, J. P. \& Chester, R. (Eds.), Chemical Oceanography. Academic Press, London. Vol. 8. 157220 pp. 1983.

[2] Nriagu, J. O. Cadmium in the environment. Part I. Ecological cycling. John Wiley \& Sons, Inc, Canada. 682 pp. 1980.

[3] Oehlmann, J. \& Schulte-Oehlmann, U. Molluscs as bioindicators, in Markert, B. A., Breure, A. M., Zechmeister, H. G. Bioindicators and biomonitors. Principles, concepts and applications. Elsevier, Oxford. 941 pp. 2003.

[4] Pacheco, M. \& Hernández-Guerra, A. Seasonal variability of recurrent phytoplankton pigment patterns in the Canary Islands area. International journal of remote sensing, 20, 1405-1418. 1999.

[5] Llinás, O., Rueda, M.J., Pérez-Martell, E. Características termohalinas y nutrientes en aguas de las plataformas insulares canarias a finales de primavera. Boletín Instituto Español de Oceanografía, 10 (2), 177-189. 1994.

[6] Davenport, R., Never, S., Helmke, P., Perez-Moreno, J. \& LLinás, O. Primary productivity in the northern Canary Islands region as inferred from seawifs imagery. Deep Sea Research II, 49, 3481-3496. 2002.

[7] Ramelow, G. J. A study of heavy metals in limpets (Patella $s p$ ) collected along a section of the southeastern Turkish Mediterranean coast. Marine Environmental Research, 16, 243-253. 1985.

[8] Miramand, P. and Bentley, D. Heavy metal concentrations in two biological indicators (Patella vulgate and Fucus serratus) collected near the French nuclear fuel reprocessing plant of La Hague. The science of the total environment, 111, 135-149. 1992.

[9] Miguel, C. S., Machado, L. M., \& Bebianno, M. J. Concentraçones de Cd, $\mathrm{Cu}$ e $\mathrm{Zn}$ em Mexilhoes Mytilus galloprovincialis e Lapas Patella aspera, ao Longo da Costa Algarvia (Sul de Portugal). Ecotoxicology and Environmental Restoration, 2 (1), 1-6. 1999.

[10] Campanella, L., Conti, M. E., Cubadda, F. \& Sucapane, C. Trace metals in seagrass, algae and molluscs from an uncontaminated area in the Mediterranean. Environmental Pollution, 111, 117-126. 2001.

[11] Cubbada, F., Conti, M. E. \& Campanella, L. Size-dependent concentrations of trace metals in four Mediterranean gastropods. Chemosphere, 45, 561-569. 2001.

[12] Navarro, P. G., Ramírez, R., Tuya, F., Fernández-Gil, C., Sánchez-Jerez, P. \& Haroun, R. J. Hierarchical analysis of spatial distribution patterns of patellid limpets in the Canary Islands. Journal of Molluscan Studies, 71, 67-73. 2005.

[13] Ramírez, R., Tuya, F., Sánchez-Jerez, P., Bergasa, O., Haroun, R. J. \& Hernández-Brito, J. J. Estructura poblacional y distribución espacial de los moluscos gasterópodos Osilinus atrata (Wood, 1828) y Osilinus sauciatus 
(Koch, 1845) en el intermareal rocoso de las Islas Canarias (Atlántico centro-oriental). Ciencias Marinas, 31 (4), 697-706. 2005.

[14] Rubio, C., Hardisson, A., Reguera, J. I., Revert, C., Lafuente, M. A. \& González-Iglesias, T. Cadmium dietary intake in the Canary Islands, Spain. Environmental Research, 100, 123-129. 2006.

[15] Moody, J. R. \& Lindstrom, R. M. Selection and cleaning of plastic containers for storage of trace element samples. Analytical Chemistry, 49, 2264-2267. 1977.

[16] Capodaglio, G., Barbante, C., Turetta, C., Scarponi, G. \& Cescon, P. Analytical quality control: sampling procedures to detect trace metals in environmental matrices. Mikrochimica Acta, 123, 129-136. 1996.

[17] Mittelstaedt, E. The ocean boundary along the northwest African coast: circulation and oceanographic properties at sea surface. Progress in Oceanography, 26, 307-355. 1991.

[18] Tuya, F., Ramírez, R., Sánchez-Jerez, P., Haroun, R. J., González-Ramos, A. J \& Coca, J. Coastal resources exploitation can mask bottom-up mesoscale regulation of intertidal populations. Hydrobiologia, 553, 337344. 2006.

[19] Tuya, F. \& Haroun, R. J. Spatial patterns and response to wave exposure of shallow water algal assemblages across the Canarian Archipelago: a multi-scaled approach. Marine Ecology Progress Series, 311, 15-28. 2006.

[20] Segovia-Zavala, J. A., Delgadillo-Hinojosa, F., Muńoz-Barbosa, A., Gutiérrez-Galindo, E. A. \& Vidal-Talamantes, R. Cadmium and silver in Mytilus californianus transplanted to an anthropogenic influenced and coastal upwelling areas in the Mexican northeastern pacific. Marine Pollution Bulletin, 48, 458-464. 2004.

[21] Banoui, A., Chiffoleau, J-F, Moukrim, A., Burgeot, T., Daaya, A., Auger, D. \& Rozuel, E. Trace metal distribution in the mussel Perna perna along the Moroccan coast. Marine Pollution Bulletin, 48, 378-402. 2004.

[22] Rainbow, P. S. Philips, D. \& Depledge, M. H. The significance of trace metal concentrations in marine invertebrates: a need for laboratory investigation of accumulation strategies. Marine Pollution Bulletin, 21, 321-324. 1990.

[23] Rainbow, P. S. \& Philips, D. Cosmopolitan biomonitors of trace metals. Marine Pollution Bulletin, 26, 593-601. 1993.

[24] Rainbow, P. S. Trace metal concentrations in aquatic invertebrates: why and so what?. Environmental Pollution, 120, 497-507. 2002.

[25] Cravo, A., Bebianno, M. J. \& Foster, P. Partitioning of trace metals between soft tissues and shells of Patella aspera. Environmental International, 30, 87-98. 2004.

[26] Van Roon, M. Availability, toxicity and uptake of heavy metals by marine invertebrates. A review with reference to the Manukau Harbour, New Zealand. Department of Planning. Working Paper Series, 99-2, pp. 17. 1999. 
[27] Cubbada, F., Enrique Conti, M. \& Campanella, L. Size-dependent concentrations of trace metals in four Mediterranean gastropods. Chemosphere, 45, 561-569. 2001.

[28] Boyden, C. R. Effect of size upon metal content of shellfish. Journal of Marine Biological Associations United Kingdom, 57, 675-714. 1977. 